\title{
Phytoplankton composition and functional groups in a tropical humic coastal lagoon, Brazil
}

\author{
Catharina Alves-de-Souza ${ }^{1}$, Mariângela Menezes ${ }^{2,3}$ and Vera Huszar ${ }^{2}$
}

Received: April 13, 2005. Accepted: March 28, 2006

\begin{abstract}
RESUMO - (Composição e grupos funcionais do fitoplâncton de uma lagoa costeira tropical húmica, Brasil). Este trabalho apresenta a composição e os grupos funcionais do fitoplâncton da lagoa Comprida, uma lagoa costeira tropical húmica localizada no sudeste brasileiro. Foi registrado um total de 28 táxons distribuídos em oito divisões taxonômicas: 26\% Heterokontophyta, $21 \%$ Chlorophyta, 21\% Cyanophyta, 14\% Bacillariophyta, 14\% Cryptophyta e 4\% Prymnesiophyta. Vinte e três táxons foram identificados em nível específico e intraespecíficos, dos quais quatro constituem novos registros para o Brasil e dois para o estado do Rio de Janeiro. O fitoplâncton da lagoa Comprida esteve constituído por alguns flagelados, mas também por organismos picoplanctônicos eucariontes e procariontes, cianobactérias filamentosas e algumas diatomáceas. A biomassa foi menor que a comumente encontrada em outros sistemas lacustres e mostrou uma notável variabilidade temporal. Em relação aos grupos funcionais, as populações foram agrupadas em oito grupos: Q, Z, E, N, $\mathrm{X}_{3}, \mathrm{X}_{2}, \mathrm{~S}_{1}$ e Y, muitos dos quais típicos de sistemas oligo ou mesotróficos, tolerantes a baixas concentrações de nutrientes e sensíveis a baixos valores de $\mathrm{pH}$.
\end{abstract}

Palavras-chave: fitoplâncton, trópicos, sistemas húmicos, lagoas costeiras, grupos funcionais, sudeste do Brasil

\begin{abstract}
Phytoplankton composition and functional groups in a tropical humic coastal lagoon, Brazil). This paper presents the composition and functional groups of the phytoplankton from Comprida lagoon, a tropical humic coastal Lagoon located in Southeast Brazil. A total of 28 taxa was found, distributed in eight taxonomic divisions as follows: $26 \%$ Heterokontophyta, $21 \%$ Chlorophyta, $21 \%$ Cyanophyta, 14\% Bacillariophyta, 14\% Cryptophyta, and 4\% Prymnesiophyta. Twenty-three taxa were identified at the specific and infraspecific levels, from which four are new records for Brazil and two for Rio de Janeiro State. Phytoplankton of the Comprida lagoon was comprised of several flagellates, but also eukaryote and prokaryote picoplankton, filamentous cyanobacteria and several diatoms. The biomass was lower than that found in other lacustrine systems, and showed remarkable temporal variability. According to the functional-group approach, the populations formed eight groups: $\mathrm{Q}, \mathrm{Z}, \mathrm{E}, \mathrm{N}, \mathrm{X}_{3}, \mathrm{X}_{2}, \mathrm{~S}_{1}$ and $\mathrm{Y}$, most typical of oligo- or mesotrophic systems, tolerant to nutrient deficiency and sensitive to increased $\mathrm{pH}$.
\end{abstract}

Key words: phytoplankton, tropics, humic systems, coastal lagoons, functional groups, Southeast Brazil

\section{Introduction}

Traditionally, humic lakes are associated with low productivity, species richness and phytoplankton population densities (Luœciñska \& Soska 1998). Dissolved humic substances can influence the physical characteristics of ecosystems (light attenuation, reduction of $\mathrm{pH}$ values and nutrient availability), as well as biological aspects in terms of biological enhancing effects and adaptations in the plankton food web (McKnight \& Aiken 1998; Nürnberg \& Shaw 1998). Therefore, lakes with high concentration of humic compounds are identified as a distinct class of systems, easily recognized by their dark-colored water (Hessen
\& Tranvik 1998). In regard to phytoplankton composition, they frequently show high contribution of chrysophytes and cryptomonads, both with mixotrophic taxa (Jones 1998; Drakare et al. 2002; M. Järvinen, unpublished data; Pålsson \& Granéli 2004).

Most of the studies on phytoplankton of humic systems are restrict to stratified and deep temperate lakes. In tropical areas, there are very few studies on phytoplankton communities in this kind of system and in South America most of the studies are from blackwater systems located in the Amazonian region (Marlier 1967; Schmidt \& Uherkovich 1973; Schmidt 1970; 1976; Fisher 1979; Thomasson 1955; 1971; Uherkovich \& Rai 1979; Uherkovich 1976; 1981). These studies

\footnotetext{
1 Universidad Austral de Chile, Instituto de Biología Marina "Dr. Jürgen Winter”, Casilla 567, Campus Isla Teja, Valdivia, Chile (cathsouza@surnet.cl)

2 Universidade Federal do Rio de Janeiro, Laboratório de Ficologia, Departamento de Botânica, Museu Nacional, Quinta da Boa Vista s/n, 20940-040 São Cristóvao, RJ, Brasil (vhuszar@gbl.com.br)

3 Corresponding Author: mmenezes@mn.ufrj.br
} 
indicate the presence of an algal flora with a high percentage of desmids and diatoms, with low phytoplankton productivity and population densities. Other studies from humic freshwater coastal lagoons at the Southern and Southeastern regions show, in general, the same properties and an important contribution of small chlorococcal green algae and picoplanktonic cyanobacteria to total phytoplankton biomass (Callegaro 1981; Huszar \& Esteves 1988; Huszar et al. 1989; Dias \& Barroso 1998; Melo \& Suzuki 1998; Roland 1998; Pålsson \& Granéli 2004). However, little importance is given to the phytoflagellates.

Phytoplankton functional groups have been used to indicate environmental conditions and have proved to be more precise than phylogenetic groups (Huszar \& Caraco 1988; Kruk et al. 2002). In the scheme proposed by Reynolds (1997) and updated by Reynolds et al. (2002), phytoplankton species are grouped into 33 functional groups, nominated by alphanumeric codes, based on their survival strategies, tolerances and sensitivities. Little is know about the phytoplankton of humic environments in regard to this approach. It is known, however, that some populations are more commonly found in these systems, such as chrysophytes, cryptomonads and raphidophytes, so that it is reasonable to expect that $\mathrm{E}, \mathrm{Y}$ and $\mathrm{Q}$ groups could be dominant: E group includes chrysophytes able to live usually in small and oligotrophic pools; Y group is well adapted to a wide range of habitats and is tolerant of low light; and Q group is common in humic lakes at high latitudes.

This paper offers a more comprehensive account of the phytoplankton flora of a humic tropical coastal lagoon (Comprida Lagoon, Brazil) and analyses the changes in phytoplankton composition and biomass according to functional groups.

\section{Material and methods}

Comprida Lagoon $\left(22^{\circ} 16^{\prime} \mathrm{S} ; 4^{\circ}{ }^{\circ} 39^{\prime} \mathrm{W}\right)$, located in the Municipality of Carapebus, is a shallow coastal system with a maximum depth of $3 \mathrm{~m}$ and a surface area of $0.13 \mathrm{~km}^{2}$. It belongs to the Restinga de Jurubatiba National Park which is part of a large sandy coastal plain on the Northeastern coast of Rio de Janeiro State (Fig. 1). This lagoon has brown-colored, acidic freshwater (mean $\mathrm{pH}=4.9$ ) with a high concentration of dissolved organic carbon (DOC) (mean $=41-74 \mathrm{mg} \mathrm{L}^{-1}$ ) due to high concentrations of humic compounds (Branco et al. 2000). High

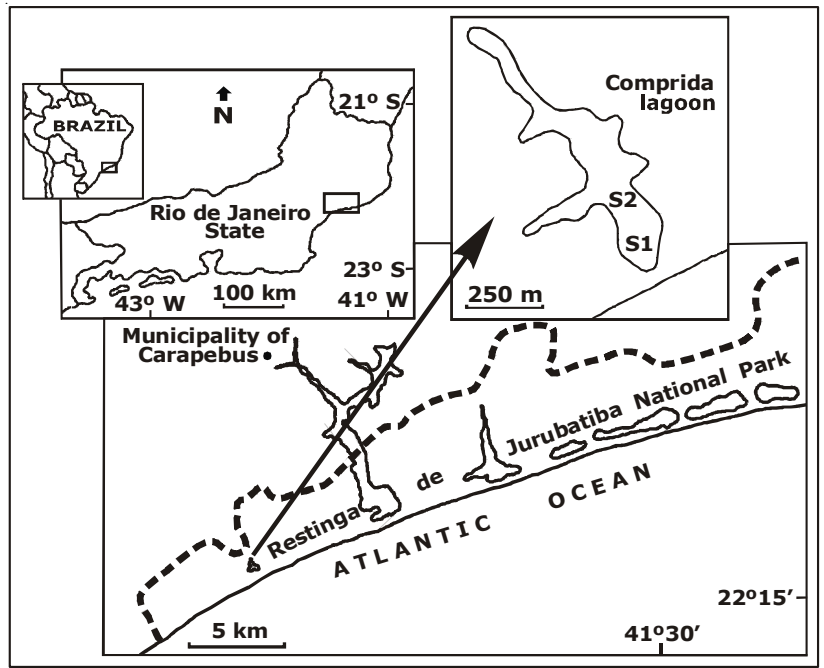

Figure 1. Location of Comprida Lagoon along the Brazilian coast and sampling stations ( $\mathrm{S} 1=$ Station $1 ; \mathrm{S} 2=$ Station). The dashed line indicates the limit of the National Park of "Restinga de Jurubatiba".

concentrations of DOC affect light penetration, leading to a high coefficient of light extinction, resulting in the heterotrophic metabolism observed during a diel cycle in this lagoon (Thomaz et al. 2001). Although the lagoon is separated from the sea by a $50 \mathrm{~m}$-wide sand bar, it shows little marine influence, which is probably only caused by the entrance of seawater during storms or high tides (Branco et al. 2000).

The surrounding lagoon area is occupied by sand dunes and shrubby vegetation, and macrophytes such as Typha domingensis Pers. are often found in the margins, forming extensive banks (Henriques et al. 1986). The local climate is sub-humid, with an annual mean relative humidity of $81 \%$, maximum average temperature of $28^{\circ} \mathrm{C}$ and minimum average temperature of $19.5^{\circ} \mathrm{C}$ (Marinho et al. 2002). Annual rainfall reaches $1244 \mathrm{~mm}$ (Marinho et al. 2002) with monthly values reaching about $300 \mathrm{~mm}$ in the rainy period (CIDE 2003).

This study was based on 14 samples taken at two stations: Station 1 (S1), located closer to the sea, and Station 2 (S2), located near the banks of macrophytes (Fig. 1). Sampling was carried out in February, March, July, and October 1996 and April, August and November 1997. Samples were obtained by passing a flask along the subsurface water then fixing with acetic Lugol's solution. Water temperature was taken with an YSI temperature/conductivity meter (YSI-30), $\mathrm{pH}$ with a $\mathrm{pH}$ meter (DIGIMED), water transparence by Secchi disk and salinity was estimated based on the conductivity and temperature according to Fofonoff and Millard (1983). 
Identification of taxa was based on light microscope observations of live and preserved material. The classification system followed Round et al. (1990) for diatoms and Hoek et al. (1997) for other algal divisions. Taxa names preceded by one or two asterisks represent new records for Brazil or for Rio de Janeiro State, respectively.

Phytoplankton densities were estimated by the settling technique with an inverted microscope (Utermöhl 1958). Units (cell, colonies and filaments) were quantified in random fields of view (Uhelinger 1964), and at least 100 specimens of the most frequent taxa ( $\mathrm{p}<0.05)$ were enumerated (Lund et al. 1958). Specific biomass was estimated from the product of population densities and mean unit volume (Edler 1979), assuming a specific density of phytoplankton cells of $1 \mathrm{~g} \mathrm{~cm}^{-3}$. Phytoplankton assemblages were classified in terms of morpho-functional categories following Reynolds et al. (2002).

\section{Results}

A total of 28 taxa was found, distributed in eight taxonomic divisions as follow: $26 \%$ Heterokontophyta, 21\% Chlorophyta, 21\% Cyanophyta, 14\% Bacillariophyta, $14 \%$ Cryptophyta, and 4\%
Prymnesiophyta. Twenty-three taxa were identified at the specific and infraspecific levels, from which four are new records for Brazil and two for Rio de Janeiro State. Table 1 presents the taxa recorded from Comprida Lagoon.

Phytoplankton shows important biomass values of flagellates (Dinobryon sertularia, Gonyostomum semen, Heterosigma cf. akashiwo, aff. Teleaulax sp. and Cryptomonas brasiliensis), eukaryote and prokaryote picoplankton (Chlorella minutissima, Choricystis minor and Synechococcus nidulans), filamentous cyanobacteria (Planktolyngbya limnetica) and diatoms (Synedra nana and Eunotia incisa).

According to changes in phytoplankton biomass and composition, we recognized three periods during this study: Period I (Feb-Mar-Jul/1996), characterized by relatively low biomass and dominated by heterokontophytes and chlorophytes; Period II (Oct/1996 and Apr/1997) also with relatively low biomass but with dominance of cyanobacterias, heterokontophytes and diatoms; and Period III (Aug and Nov/1997), with the highest biomass and dominance of cryptomonads and chlorophytes (Fig. 2).

Water temperature varied from 22 to $31.5^{\circ} \mathrm{C}$, and July/1996 and August/1997 were the coldest months

Table 1. Phytoplankton species recorded from Comprida lagoon during the study period. Species indicated with * and ** are new records to Brazil and Rio de Janeiro State, respectively.

\begin{tabular}{|c|c|}
\hline CYANOPHYTA & Ochromonas sp. \\
\hline Cyanophyceae & Raphydophyceae \\
\hline Chroococcus microscopicus Komárková et Cronberg & Gonyostomum semen (Ehrenberg) Diesing \\
\hline $\begin{array}{l}\text { **Eucapsis densa Azevedo, Sant’Anna, Senna, } \\
\text { Komárek \& Komárková }\end{array}$ & $\begin{array}{l}\text { Heterosigma } \text { cf. akashiwo (Hada) Hada ex Hara \& Chihara } \\
\text { Merotrichia bacillata Mereschkowsky }\end{array}$ \\
\hline Jaaginema subtilissimum (Kützing ex De Toni) & PRYMNESIOPHYTA \\
\hline Anagnostidis et Komárek & Prymnesiophyceae \\
\hline Planktolyngbya limnetica (Lemmermann) Komárková & *Diachronema vlkianum Pranser \\
\hline \& Cronberg & CRYPTOPHYTA \\
\hline Rabdoderma lineare Schmidle \& Lauterborn & Cryptophyceae \\
\hline *Synechococcus nidulans (Pringsheim) Komárek & Chroomonas acuta Utermöhl \\
\hline BACILLARIOPHYTA & Chroomonas nordstedtii Hansgirg \\
\hline $\begin{array}{l}\text { Coscinodiscophyceae } \\
\text { Cyclotella meneghiniana Kützing }\end{array}$ & $\begin{array}{l}\text { Cryptomonas brasiliensis Castro, C. Bicudo \& D. Bicudo } \\
\text { aff. Teleaulax sp. }\end{array}$ \\
\hline Fragilariophyceae & CHLOROPHYTA \\
\hline **Synedra nana Meister & Prasinophyceae \\
\hline Bacillariophyceae & Scourfieldia cordiformis Takeda \\
\hline Eunotia incisa W. Smith ex Gregory & Chlorophyceae \\
\hline Nitzschia palea (Kützing) W. Smith & Chlamydomonas sp. \\
\hline HETEROKONTOPHYTA & Chlorella minutissima Fott \& Nováková \\
\hline Chrysophyceae & Choricystis minor (Skuja) Fott \\
\hline Dinobryon sertularia Ehrenberg & *Klebsormidium pseudostichococcus (Heering) \\
\hline Epipyxis sp. & Ettl \& Gärtner \\
\hline *Monochrysis parva Skuja & Tetraedrum caudatum (Corda) Hansgirg \\
\hline
\end{tabular}


during the study period ( 22 and $23{ }^{\circ} \mathrm{C}$, respectively). Low $\mathrm{pH}$ values were observed, with an average, by period, varying from 5.0 to 5.8. Little marine influence (0.36-1.24\%o) was found during the study period, the highest salinity values observed during Period III
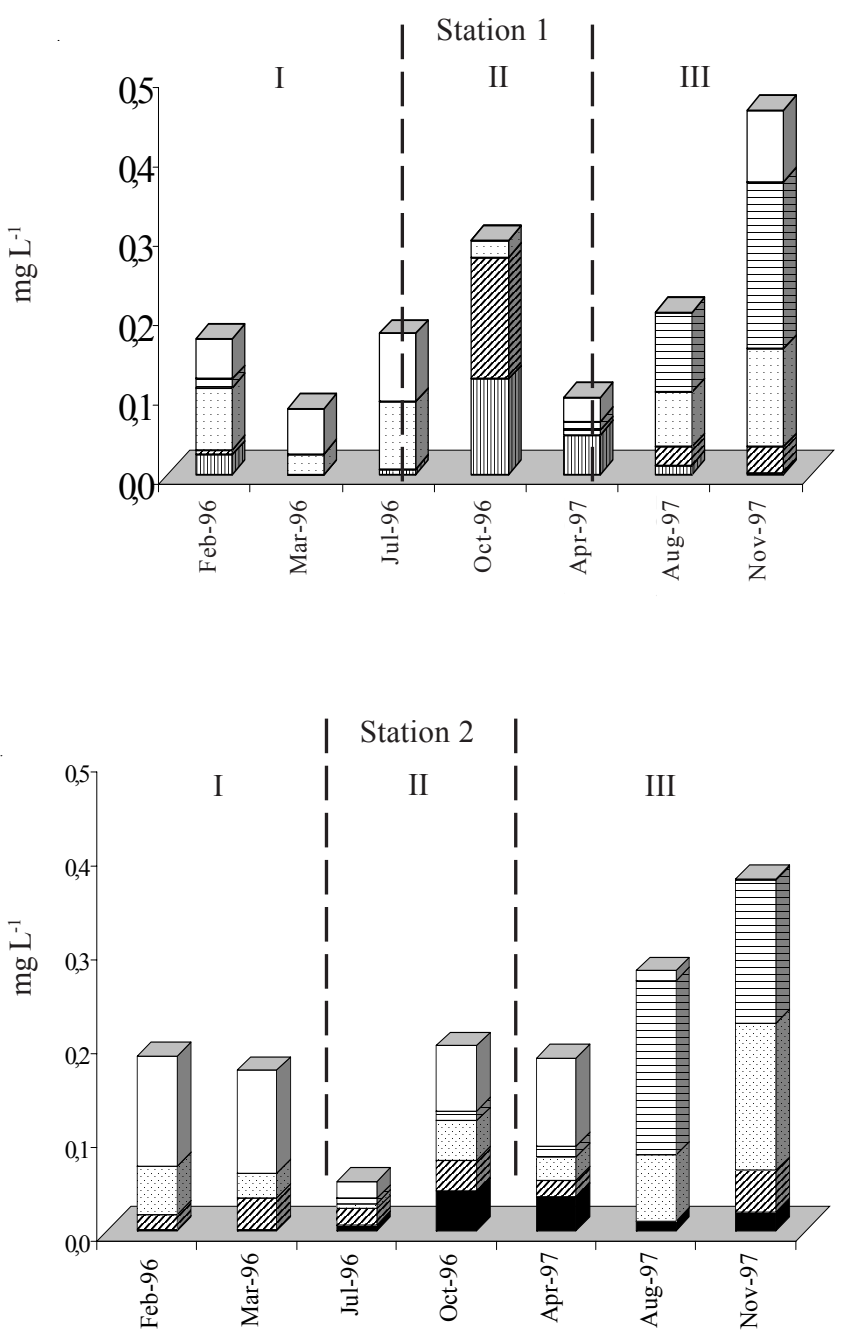

Figure 2. Contribution of phytoplankton biomass $\left(\mathrm{mg} \mathrm{L}^{-1}\right)$ by taxonomic divisions to the total phytoplankton of Comprida lagoon by period ( $\mathrm{I}=$ Period I; II = Period II; III = Period III) in surface of Stations 1 and 2 (S1 and S2). 四 = Cyanobacteria; $\mathbb{Q}$ = Diatoms; $⿴$ = Chlorophytes; 目 = Cryptophytes; $\square=$ Heterokontophytes.
(Tab. 2). Although a difference was observed in phytoplankton composition and biomass values between the three periods, among the abiotic variables only salinity followed this difference.

Phytoplankton biomass was low and showed remarkable variability between the three periods. Period I was characterized by the lowest mean biomass (0.14 $\left.\mathrm{mg} \mathrm{L}^{-1}\right)$, dominated by Chlorella minutissima and Dinobryon sertularia in Station 1, and by Gonyostomum semen and cysts of Heterosigma cf. akashiwo in Station 2. Period II, with mean phytoplankton biomass of $0.18 \mathrm{mg} \mathrm{L}^{-1}$, was characterized by the dominance of Eunotia incisa, Planktolyngbya limnetica and Synechococcus nidulans in Station 1, and Gonyostomum semen, Synedra nana and Synechococcus nidulans in Station 2. Period III showed the highest mean biomass values during the study period $\left(0.33 \mathrm{mg} \mathrm{L}^{-1}\right)$, with dominance of aff. Teleaulax sp., vegetative cells of Heterosigma cf. akashiwo and Cryptomonas brasiliensis in Station 1, and aff. Teleualax sp., Chlorella minutissima, Choricystis minor and Cryptomonas brasiliensis in Station 2. These populations were classified into eight functional groups (Q, Z, E, N, $\mathrm{X}_{3}, \mathrm{X}_{2}, \mathrm{~S}_{1}$ and $\mathrm{Y}$ ) as specified in Table 3.

\section{Discussion}

Based on nutrient data (Branco et al. 2000), Comprida Lagoon could be classified as having distinct trophic states, depending on the criteria used either for warm lakes (Salas \& Martino 1991) or for temperate lakes (Nürnberg 1996). It is important to mention that the proportion of organic nitrogen $(\mathrm{N})$ in Comprida Lagoon is higher when compared with dissolved inorganic levels, which indicates $\mathrm{N}$ deficiency for phytoplankton growth (Reynolds 1997). Considering the limiting concentrations of soluble reactive phosphorus (mean $\left.=2.29 \mu \mathrm{g} \mathrm{l}^{-1}\right)$ and the low levels of chlorophyll $\left(\right.$ mean $\left.=2.72 \mu \mathrm{g} \mathrm{L}^{-1}\right)$ mentioned in Branco

Table 2. Average and minimum and maximum values of some abiotic variables, in the surface of the Comprida lagoon, by periods.

\begin{tabular}{|c|c|c|c|c|c|c|}
\hline & \multicolumn{2}{|c|}{$\begin{array}{c}\text { Period I } \\
\text { (Feb, Mar and Jul/96) }\end{array}$} & \multicolumn{2}{|c|}{$\begin{array}{c}\text { Period II } \\
\text { (Oct/96 and Apr/97) }\end{array}$} & \multicolumn{2}{|c|}{$\begin{array}{c}\text { Period III } \\
\text { (Aug and Nov/97) }\end{array}$} \\
\hline & Average & Min-Max & Average & Min-Max & Average & Min-Max \\
\hline Transparency (m) & 0.3 & $0.3-0.5$ & 0.3 & $0.3-0.5$ & 0.3 & $0.3-0.5$ \\
\hline Water temperature $\left({ }^{\circ} \mathrm{C}\right)$ & 26.6 & $22-31$ & 25.5 & $25-26$ & 25.6 & $23-32$ \\
\hline $\mathrm{pH}$ & 5.45 & $4.4-6.8$ & 5.1 & $4.6-5.4$ & 5.1 & $5.1-6.2$ \\
\hline Salinity (\%o) & 0.35 & $0.2-0.4$ & 0.35 & $0.3-0.4$ & 1.1 & $0.8-1.4$ \\
\hline
\end{tabular}


Table 3. Relative contribution (\%) based on biomass of the main phytoplankton functional groups (FG.) by period, of surface samples taken at Stations 1 and 2 (S1 and S2) of Comprida lagoon.

\begin{tabular}{|c|c|c|c|c|c|c|c|c|c|}
\hline & \multicolumn{3}{|l|}{$\begin{array}{l}\text { Period I } \\
\text { (Feb, Mar and Jul/96) }\end{array}$} & \multicolumn{3}{|c|}{$\begin{array}{l}\text { Period II } \\
\text { (Oct/96 and Apr/97) }\end{array}$} & \multicolumn{3}{|l|}{$\begin{array}{l}\text { Period III } \\
\text { (Aug and Nov/97) }\end{array}$} \\
\hline & & $\%$ & FG & & $\%$ & FG & & $\%$ & FG \\
\hline \multirow[t]{8}{*}{$\mathrm{S} 1$} & C. minutissima & 40 & $\mathrm{X}_{3}$ & E. incisa & 39 & $\mathrm{~N}$ & aff. Teleaulax sp. & 27 & $\mathrm{Y}$ \\
\hline & D. sertularia & 21 & $\mathrm{E}$ & P. limnetica & 29 & $\mathrm{~S}_{1}$ & C. brasiliensis & 14 & $\mathrm{Y}$ \\
\hline & H. cf. akashiwo (cysts) & 13 & Q & S. nidulans & 14 & $\mathrm{Z}$ & H. cf. Akashiwo (vegetative cells and cysts) & 14 & Q \\
\hline & & & & C. minutissima & 7 & $X_{3}$ & & & \\
\hline & G. semen & 7 & Q & H. cf. akashiwo & 7 & Q & C. minor & 13 & $\mathrm{X}_{3}$ \\
\hline & S. nidulans & 7 & $\mathrm{Z}$ & (cysts) & & & C. minutissima & 10 & \\
\hline & & & & & & & S. nana & 8 & \\
\hline & & & & & & & S. cordiformis & 6 & $\mathrm{X}_{2}$ \\
\hline \multirow[t]{6}{*}{ S2 } & G. semen & 31 & Q & G. semen & 26 & Q & aff. Teleaulax sp. & 34 & Y \\
\hline & H. cf. akashiwo(cysts) & 15 & Q & S. nana & 13 & $\mathrm{~N}$ & C. minutissima & 18 & $\mathrm{X}_{3}$ \\
\hline & & 14 & $\mathrm{X}_{3}$ & S. nidulans & 12 & $\mathrm{Z}$ & C. minor & 16 & $\mathrm{X}_{3}$ \\
\hline & C. minutissima & 12 & $\mathrm{~N}$ & C. minutissima & 8 & $\mathrm{X}_{3}$ & C. brasiliensis & 13 & $\mathrm{Y}$ \\
\hline & E. incisa & 8 & $\mathrm{E}$ & P. limnetica & 8 & $\mathrm{~S}$ & & & \\
\hline & D. sertularia & & & aff. Teleaulax sp. & 6 & $\mathrm{Y}$ & & & \\
\hline
\end{tabular}

et al. (2000), Comprida Lagoon can be classified as an oligotrophic system using both warm lake and temperate lake criteria. However, at least for tropical systems, phytoplankton species composition may be more informative for the classification of lake trophic state than other trophic indicators such as nutrients, transparence or chlorophyll (Huszar et al. 1998). Indeed, the dominant functional groups of Comprida Lagoon were indicative of an oligo-mesotrophic system.

Most of the knowledge on phytoplankton of humic systems is restricted to stratified and deep temperate lakes. In these environments, phytoplankton communities include, in general, few species of phytoflagellates, which can optimise their access to light and nutrients by vertical migration (Bowling \& Tyler 1988). Phytoplankton of the Comprida Lagoon was composed of some flagellates, but also contained eukaryote and prokaryote picoplankton, filamentous cyanobacterias and some metaphytic diatoms. Although turbulent humic lakes exhibit a strong contribution of phytoflagellates, they also show a more diverse phytoplankton community, including a higher proportion of diatoms (Jones 1998).

Mixotrophy has been thought to be a particularly successful strategy in humic systems (Drakare et al. 2002; M. Järvinen, unpublished data), where low light and low dissolved inorganic nutrients are limiting to phytoplankton growth, and high concentration of dissolved organic matter leads to high bacterial density (Jones 2000). However, there is very little information on the importance of mixotrophic phytoflagellates in tropical humic systems. Pålsson \& Granéli (2004) compared the phytoplankton of three temperate humic lakes with three tropical humic lagoons (among them Comprida Lagoon) and recorded that the mixotrophic biomass was low in the tropical systems and constituted only $1-7 \%$ of the total biomass. These data are in disagreement with our results to Comprida Lagoon, when the species indicated by these authors as mixotrophic constituted $5-50 \%$ of total biomass at some sampling dates. This discordance may be explained because the results of Pålsson \& Granéli (2004) were based on only in one sample collected in the summer of 1998 and a higher number of samples at different times of the year might be necessary to characterize the presence mixotrophic flagellates in tropical humic systems.

As observed in temperate humic systems, the potential mixotrophics (heterokontophytes and cryptophytes) played an important role in the phytoplankton community of Comprida Lagoon. Dinobryon sertularia is known to be potentially mixotrophic, showing facultative bacterial feeding (Jones \& Rees 1994; Pugnetti \& Bettinetti 1999) and Gonyostomum semen has the facultative capacity of heterotrophy by osmotrophy (Eloranta \& Järvinen 1989). Indeed, many phytoplankton species, like Cryptomonas spp., can take up dissolved organic carbon or, under inorganic nutrient deficiency, can use dissolved amino acids or other organic sources of 
nitrogen (Schoonhoven 2000).

Despite the fact that planktonic flora of Comprida Lagoon was typically limnobiont euryhaline, one marine euryhaline taxa, Heterosigma cf. akashiwo, was observed. A very small marine influence was observed, however, during Period III when salinity values were slightly higher (Tab. 2). This difference in salinity values was reflected in the floristic composition throughout the study period: although cysts of $H$. cf. akashiwo were commonly observed during the entire study, some vegetative cells were present only in Period III. Indeed, some individuals of Prorocentrum minimum (Pavillard) Schiller, a marine euryhaline species, were recorded in net samples and also only in Period III (Alves-deSouza et al. unpublished data).

According to the functional group approach, the populations were classified in eight groups (Tab. 3). Thus, Gonyostomum semen, dominant in Comprida Lagoon during Period I, can be recognized as a representative species of group Q, which is common in humic lakes of high latitudes (Cronberg et al. 1988), usually having low calcium contents and acidic waters (Reynolds et al. 2002). This species was also found forming bloom in a shallow, humic artificial pond in a Brazilian tropical region (M. Menezes, unpublished data). In this same group we are now also including another raphidophyte, Heterosigma cf. akashiwo, which was co-dominant during Period III.

Dinobryon sertularia, a representative of group $\mathrm{E}$, is sensitive to $\mathrm{CO}_{2}$ deficiency and usually able to live in small, oligotrophic or heterotrophic ponds. Mixotrophy may be an advantageous strategy in these particular conditions. Some diatoms, such as Synedra nana and Eunotia incisa, although typical metaphytic species, conbtributed somewhat to the phytoplankton biomass of Comprida Lagoon. Despite the functional group approach having been developed for pelagic vegetation, both species can be thought of as $\mathrm{N}$-functional group. We are now including them in group $\mathrm{N}$, which is characterized by strong dependence of physical mixing and could be present in acidic shallow lakes with low values of nutrients (Reynolds et al. 2002).

Small size representatives of non-motile nanoplankton $\left(\mathrm{X}_{3}-\right.$ Choricystis minor and Chlorella minutissima) and also prokaryote picoplankton ( $\mathrm{Z}$ - Synechococcus nidulans) had an important contribution to the phytoplankton biomass in this study. $\mathrm{X}_{3}$ and $\mathrm{Z}$ groups are expected to live in shallow, clear and mixed layers, being sensitive to light deficiency and grazing (Reynolds et al. 2002). Although these groups are not expected to occur in dark water systems, non-motile nanoplankton (Dias \& Barroso 1998) and prokariotic picoplankton (Roland 1998; Melo \& Suzuki 1998) could also be co-dominant in humic systems. The dominance of $C$. minor was also recorded from a temperate partially polymictic humic lake and could be a result of the capacity of this small alga to respond rapidly to nutritional conditions (Hechmann et al. 2001).

Group $\mathrm{Y}$ is well adapted to live in a wide range of habitats and is tolerant of low light and sensitive to grazing, being commonly observed in humic lakes (Jones 1998). Cryptomonas brasiliensis and an aff. Teleaulax sp. were also important to phytoplankton of Comprida Lagoon.

In synthesis, our data show that in tropical systems, besides the phytoflagellates, the chlorophytes, cyanobacterias and diatoms may be important components of phytoplankton and, due to the high proportion of potential mixotrophics, the mixotrophy may also be considered a successful strategy, as observed in temperate humic systems. Finally, the functional group approach constitutes a useful tool understanding the phytoplankton community in tropical humic systems, despite having been originally formulated for temperate systems.

\section{Acknowledgements}

We wish to thank Lúcia Helena Sampaio da Silva (MN/UFRJ) and Sérgio Melo (INPA), for their assistance in the analysis of some samples and suggestions, Maria Celia Villac (UNITAU) and Lauri Arvola (University of Helsinki) for manuscript revision and suggestions, respectively. The present study was supported by CNPq, FAPERJ, UFRJ and FUJB.

\section{References}

Bowling, L.C. \& Tyler, P.A. 1988. Lake Chisholm, a polyhumic forest lake in Tasmania. In: Jones, R. I. \& Ilmavirta, V. (eds.). Flagellates in freshwater ecosystems. Developments in Hydrobiology 45: 55-67.

Branco, C.W.C.; Esteves, F.A. \& Kozlowsky-Suzuki, B. 2000. The zooplankton and other limnological features of a humic coastal lagoon (Lagoa Comprida, Macaé, RJ) in Brazil. Hydrobiologia 437: 71-81.

Callegaro, V.L.M. 1981. Estudo de comunidades fitoplanctônicas da Lagoa Negra, Parque Estadual de Itapuã, Rio Grande do Sul, Brasil. Iheringia 28: 157-167.

CIDE. 2003. Variações climáticas recentes no estado do Rio de Janeiro. Índice de qualidade dos MunicípiosVerde II (IQM-Verde II). Hypertext. Home page http:// 200.156.34.70/IQM/VerdeII/cap.6.htm (captured in Feb/02/2004). 
Cronberg, G.; Lindmark, G. \& Björk, S. 1988. Mass development of the flagellate Gonyostomum semen (Raphidophyceae) in Swedish forest lakes - an effect of acidification? In: R.I. Jones \& V. Ilmavirta (eds.). Flagellates in freshwater ecosystems. Developments in Hydrobiology 45: 217-236.

Dias Jr., C. \& Barroso, G.F. 1998. Limnological studies of coastal lagoons in the south Espírito Santo State (Brazil). Verhandlungen Internationale Vereinigung für Theoretische und Angewandte Limnologie 26: 1433-1437.

Drakare, S.; Blomqvist, P.; Bergstrom, A. \& Jansson, M. 2002. Primary production and phytoplankton in relation to DOC input and bacterioplankton production in humic Lake Örträsket. Freshwater Biology 47: 41-52.

Edler, L. 1979. Recommendations for marine studies in the Baltic Sea. Phytoplankton and chlorophyll. Unesco, Working Group 11, Marine Biologists.

Eloranta, P. \& Järvinen, M. 1989. Growth of Gonyostomum semen (Ehr.) Diesing (Raphidophyceae): Results from culture experiments. Verhandlungen Internationale Vereinigung für Theoretische und Angewandte Limnologie 24: 2657-2659.

Fisher, T.R. 1979. Plankton and primary production in aquatic systems of central Amazon. Journal of Comparative Biochemistry and Physiology Part A: Physiology 62: 31-38.

Fofonoff, P. \& Millard Jr., R.C. 1983. Algorithms for computation of fundamental properties of seawater. Unesco Technical Papers in Marine Science 44.

Hechmann, A.; Krienitz, L. \& Rainer, K. 2001. Long-term phytoplankton changes in an artificially divided, top down manipulated humic lake. Hydrobiologia 448: 83-96.

Henriques, R.P.M.; Araújo, D.S.D. \& Hay, J.D. 1986. Descrição e classificação dos tipos de vegetação da restinga de Carapebus, Rio de Janeiro. Revista Brasileira de Botânica 9: 173-189.

Hessen, D.O. \& Tranvik, L.J. 1998. Humic substances as ecosystem modifiers - Introduction. Pp. 1-6. In: D.O. Hessen \& L.J. Tranvik (eds.). Aquatic humic substances: ecology and biogeochemistry. Germany, Springer.

Hoek, C. van den; Mann, D.G. \& Jahns, H.M. 1997. Algae: an introduction to phycology. Cambridge, Cambridge University Press.

Huszar, V.L.M. \& Carraco, N. 1998. The relationship between phytoplankton composition and physical-chemical variables: a comparison of taxonomic and morphologicalfunctional groups approaches in six temperate lakes. Freshwater Biology 40: 1-18.

Huszar, V.L.M. \& Esteves, F.A. 1988. Considerações sobre o fitoplâncton de rede de 14 lagoas costeiras do estado do Rio de Janeiro, Brasil. Acta Limnologica Brasiliensis 2: 323-346.

Huszar, V.L.M.; Menezes, M. \& Fernandes, V.O. 1989. Fitoplâncton de rede da lagoa de Cabiúnas, Macaé, Rio de Janeiro, Brasil: uma contribuição a seu conhecimento. Boletim do Museu Nacional do Rio de Janeiro, Nova Série, Botânica 78: 1-43.
Huszar, V.L.M.; Silva, L.H.S.; Domingos, P.; Marinho, M.M. \& Melo, S. 1998. Phytoplankton species composition is more sensitive than OECD criteria to the trophic status of three Brazilian lakes. Hydrobiologia 129: 59-71.

Jones, R.I. 1998. Phytoplankton, primary production and nutrient cycling. Pp. 145-175. In: D.O. Hessen \& L.J. Tranvik (eds.). Aquatic humic substances: ecology and biogeochemistry. Germany, Springer.

Jones, R.I. 2000. Mixotrophy in planktonic protists: an overview. Freshwater Biology 45: 219-226.

Jones, R.I. \& Rees, S. 1994. Influence of temperature and light on particle ingestion by the freshwater phytoflagellate Dinobryon. Archiv für Hydrobiologie 132: 203-211.

Kruk, C.; Mazzeo, N.; Lacerot, G. \& Reynolds, C.S. 2002. Classification schemes for phytoplankton: a local validation of a functional approach to the analysis of species temporal replacement. Journal of Plankton Research 24: 1191-1216.

Lund, J.W.G.; Kipling, C. \& Lecren, E.D. 1958. The inverted microscope method of estimating algal number and the statistical basis of estimating by counting. Hydrobiologia 11: 143-170.

Luœciñska, M. \& Soska, R. 1998. Algal communities of humic acid sites: biomass and diversity in lake water versus peat-mat water. Polish Journal of Ecology 46: 123-135.

Marinho, C.S.; Monnera, P.H.; Carvalho Jr., A.C.; Marins, S.L.D. \& Vieira, A. 2002. Análise química do pecíolo e limbo foliar como indicadores do estado nutricional dos mamoeiro 'solo' e 'formosa'. Scientia Agricola 59: 373-381.

Marlier, G. 1967. Ecological studies on some lakes of the Amazon Valley. Amazoniana 1: 91-115.

McKnight, D.M. \& Aiken, G.R. 1998. Sources and characterization on aquatic humus. Pp. 9-39. In: D.O. Hessen \& L.J. Tranvik (eds.). Aquatic humic substances: ecology and biogeochemistry. Germany, Springer.

Melo, S. \& Suzuki, M. 1998. Variações temporais e espaciais do fitoplâncton das lagoas Imboassica, Cabiúnas e Comprida. Pp.177-203. In: F.A. Esteves (ed.). Ecologia das lagoas costeiras do Parque Nacional da Restinga de Jurubatiba e do município de Macaé (RJ). Rio de Janeiro, Núcleo de Pesquisas Ecológicas de Macaé, Universidade Federal do Rio de Janeiro.

Nürnberg, G.K. 1996. Trophic state of clear and colored, soft- and hardwater lakes with special consideration of nutrients, anoxia, phytoplankton and fishes. Journal of Lake and Reservoir Management 12: 432-447.

Nürnberg, G.K. \& Shaw, M. 1998. Productivity of clear and humic lakes: nutrients, phytoplankton, bacteria. Hydrobiologia 382: 97-112.

Pålsson, C. \& Granéli, W. 2004. Nutrient limitation of autotrophic and mixotrophic phytoplankton in a temperate and tropical humic lake gradient. Journal of Plankton Research 26: 1005-1014. 
Pugnetti, A. \& Bettinetti, R. 1999. Biomass and species structure of the phytoplankton of a high mountain lake (Lake Paione Superiore, Central Alps, Italy). In: V. Straškrabová; C. Callieri \& J. Fott (eds.). Pelagic food web in mountain lakes, Mountain Lakes Research Program. Journal of Limnology 58: 127-130.

Reynolds, C.S. 1997. Vegetation processes in the pelagic: a model for ecosystem theory. Germany, Ecology Institute.

Reynolds, C.S.; Huszar, V.; Kruk, C.; Naselli-Flores, L. \& Melo, S. 2002. Towards a functional classification of the freshwater phytoplankton. Journal of Plankton Research 24: 417-428.

Roland, F. 1998. Produção fitoplanctônica em diferentes classes de tamanho nas lagoas Imboassica e Cabiúnas. Pp. 160-172. In: F.A. Esteves (ed.). Ecologia das lagoas costeiras do Parque Nacional da Restinga de Jurubatiba e do município de Macaé (RJ). Rio de Janeiro, Núcleo de Pesquisas Ecológicas de Macaé, Universidade Federal do Rio de Janeiro.

Round, F.E.; Crawford, R.M. \& Mann, D.G. 1990. The diatoms: biology and morphology of genera. Cambridge, Cambridge University Press.

Salas, H.J. \& Martino, P. 1991. A simplified phosphorus trophic state model for warm-water tropical lakes. Water Research 25: 341-350.

Schoonhoven, E. 2000. Ecophysiology of mixotrophs. Hypertext. Home page: http://www.bio.vu.nl/thb/ education/Scho2000.pdf (captured in Dez/19/2003).

Schmidt, G.W. 1970. Numbers of bacteria and algae and their interrelations in some Amazonian waters. Amazoniana 2: 393-400.
Schmidt, G.W. 1976. Primary production of phytoplankton in the three types of Amazonian waters. V. Some investigations on the phytoplankton in a bay of the lower Rio Negro (Amazonas, Brasil). Amazoniana 5: 517-528.

Schmidt, G.W. \& Uherkovich, G. 1973. Zur artenfülle des phytoplankton in Amazonien. Amazoniana 4: 243-252.

Thomasson, K. 1955. Studies on South American fresh water plankter: Amazonas. Acta Horti Gothoburg 19: 213-215.

Thomasson, K. 1971. Amazonian algae. Mémoires de l'Institut Royal des Sciences Naturelles de Belgique 86: $1-57$.

Thomaz, S.M.; Enrich-Prast, A.; Gonçalves, J.F.; Santos, A.M. \& Esteves, F.A. 2001. Metabolism and gaseous exchanges in two coastal lagoons from Rio de Janeiro with distinct limnological characteristics. Brazilian Archives of Biology and Technology 44: 433-438.

Uherkovich, G. 1976. Algen aus den Flüssen Rio Negro und Rio Tapajós. Amazoniana 5: 465-515.

Uherkovich, G. 1981. Algen aus einigen Gewässern Amazonies. Amazoniana 7: 191-219.

Uherkovich, G. \& Rai, H. 1979. Algen aus dem Rio Negro und seine Nebenflüssen. Amazoniana 6: 611-638.

Uhelinger, V. 1964. Étude statistique des methodes de dénobrement planctonique. Archive de Science 17: 121-223.

Utermöhl, H. 1958. Zur Vervollkomnung der quantitativen Phytoplankton-Methodik. Mitteilungen. Internationale Vereiningung fuer Theoretische und Angewandte Limnologie 9: 1-38. 